\title{
Prvi Slovar makedonskega knjižnega jezika s stališča kodifikacije makedonskega jezika
}

\author{
GJOKO NikOLOVSKi \\ Univerza v Mariboru, Filozofska fakulteta, Koroška cesta 160, \\ SI-2000 Maribor, gjoko.nikolovski@um.si
}

SCN VIII/1 [2015], 203-210

Prispevek obravnava prvi Slovar makedonskega jezika s srbohrvaškimi prevodi,${ }^{1}$ in sicer glede na njegov pomen pri kodifikaciji in nadaljnjem razvoju makedonskega jezika.

This paper deals with the first Macedonian language dictionary with Serbo-Croatian translations, specifically concerning its role in the consolidation and further development of the Macedonian language.

Ključne besede: makedonščina, kodifikacija, makedonsko slovaropisje, razvoj makedonskega jezika

Key words: Macedonian language, codification, Macedonian lexicography, Development of the Macedonian Language

\section{Pred izidom slovarja}

Dogodek zgodovinskega pomena za oblikovanje makedonskega knjižnega jezika, ob katerem se je porodila ideja o posebnem makedonskem jeziku, je izid knjige Za makedonckite raboti (За македониките работи) Krsteta Petkovega Misirkovega leta 1903. S to knjigo je Misirkov določil svoj nacionalni program in obravnaval vprašanje makedonskega knjižnega jezika. Zadnje poglavje knjige z naslovom Nekoliko besed o sodobnem makedonskem jezikи (Неколку зборови за македоникиот литературен јазик) je prvi argumentiran in odločno postavljen projekt o kodifikaciji makedonskega jezika. Misirkov je začel z opisom značilnosti in razvoja makedonskega jezika $v$ družini slovanskih jezikov ter

\footnotetext{
${ }^{1}$ Za analizo Slovarja makedonskega jezika s srbohrvaškimi prevodi uporabljamo 3. izdajo le-tega iz leta 1994.
} 
njegove pomembne vloge $\mathrm{v}$ nacionalnem prebujanju makedonskega naroda. Njegov pogled lahko strnemo v tri temeljne točke (Misirkov 1903: 145):

- za osnovo knjižnega jezika je vzel osrednje govore (na črti Veles-PrilepBitola-Ohrid);

- pravopis je postavil na fonetični osnovi, z majhnimi izjemami v etimologiji;

- v leksiko je vključil elemente iz vseh makedonskih govorov.

Razvoj makedonskega knjižnega jezika je bil odvisen od komplicirane zgodovine makedonskega naroda, še posebej v obdobju od začetka 19. stoletja do uradne kodifikacije. V razvoju makedonskega knjižnega jezika od 19. stoletja do končne kodifikacije razlikujemo tri faze (Koneski 1981: 151-152):

1. faza - od začetka 19. stoletja do balkanskih vojn (1912). V tem obdobju je makedonski narod živel znotraj svojih etničnih meja v Turškem imperiju, ki ni nalagal verske ali jezikovne dominacije in ki je dovoljeval relativno svobodo glede uporabe makedonskega jezika in religije;

2. faza - od konca balkanskih vojn (1913) do konca druge svetovne vojne. Makedonski narod je bil razdeljen med sosednimi državami (Grčijo, Srbijo, Bolgarijo in Albanijo), medtem ko je bila uporaba makedonskega jezika prepovedana;

3. faza - od konca druge svetovne vojne do danes. V tem obdobju je z ustanovitvijo makedonske države makedonski jezik doživel svojo kodifikacijo.

Kodifikacija makedonskega knjižnega jezika je bila povezana z:

- odločbo prvega zasedanja ASNOM ${ }^{2}$ dne 2. 8. 1944, ko je makedonski jezik postal uradni jezik v makedonski državi,

- uradnim sprejetjem makedonske pisave,

- uradnim sprejetjem makedonskega pravopisa.

Prezidium ASNOM kot najvišji organ makedonske države je v novembru 1944 imenoval Komisijo za pisavo in pravopis makedonskega jezika. Komisija je oblikovala svoja stališča $v$ Resoluciji, ki je bila sprejeta 5. 5. $1945 \mathrm{~s}$ strani Narodne vlade federativne Makedonije. Komisija za pisavo in pravopis makedonskega jezika je določila principe, ki so podobni Misirkovim, in sicer (Koneski 1996: 18):

- v makedonskem knjižnem jeziku je treba določiti narečno osnovo knjižnega jezika iz osrednjih govorov, ki bo sprejemljiva za vse govorce makedonskega jezika;

- slovar knjižnega jezika mora vsebovati besedni zaklad vseh narečij. Tvorjenje novih besed z živimi končnicami in omejeno sposojanje tujih besed;

- makedonska pisava mora vsebovati toliko črk, kolikor je glasov v knjižnem jeziku. Pravopis je treba postaviti na fonetičnem principu.

${ }^{2}$ АСНОМ - Антифашистичко собрание за народно ослободување на Македонија (Antifašistični zbor za narodno osvoboditev Makedonije). 
Pravopis makedonskega jezika je bil sprejet 7. 6. 1945. Makedonski pravopis s pravopisnim slovarjem avtorjev Blažeta Koneskega in Kruma Toševega je izšel leta 1945 (prva izdaja) in 1950 (druga izdaja). Med letoma 1952 in 1954 je izšla Slovnica makedonskega jezika I in II avtorja Blažeta Koneskega.

\section{Delo pri slovarju, izid slovarja in njegova struktura}

Po izidu pravopisa in slovnice makedonskega jezika je ostala še realizacija slovaropisnega dela, s čimer bi se zaokrožila uradna kodifikacija makedonskega jezika. Do tega je prišlo z izdajo Slovarja makedonskega jezika s srbohrvaškimi prevodi, ki je izšel v treh zvezkih od 1961 do 1966 leta. Redaktor slovarja je bil Blaže Koneski. Prvi zvezek slovarja vsebuje gradivo s črkami od A do N. Drugi zvezek je izšel leta 1963, kjer so črke od O do P. V letu 1966 je izšel zadnji zvezek, ki vsebuje gradivo s črkami od R do Š.

Delo pri slovarju, kot je zapisano v Predgovoru prvega zvezka slovarja (1994: VII), se je začelo v letu 1951. Za organizacijo dela je bila pristojna Specialna komisija za makedonski slovar, ki je bila imenovana leta 1951 s strani Ministrstva za izobraževanje SR Makedonije, v sestavi: Blaže Koneski, Mihail Petruševski in Krum Tošev. Besede so se izpisovale iz sodobnih književnih, znanstvenih in publicističnih del, iz ljudskih umetnin, iz prilog, ki so se nanašale na leksiko makedonskih narečjih ipd. Izpis se je nadaljeval $\mathrm{v}$ toku obdelave $\mathrm{z}$ besedami iz pogovornega jezika. S tem so bile zaokrožene vse zvrsti makedonskega jezika. V tem kontekstu je treba omeniti princip Blažeta Koneskega v zvezi z zbiranjem gradiva za slovar (Koneski 1981a: 37):

Како основна точка на ориентацијата служеше во овој поглед становиштето дека во македонскиот литературен јазик треба во најголема мера да се изрази неговата народна основа. Посебно во однос на лексиката се инсистираше на тоа во неа да се вклучуваат зборови од сите дијалекти, како и неологизми изведени со продуктивни наставки, а само колку што е потребно и заемки од други јазици.

Njegov princip predstavlja uresničitev ideje Misirkovega (Misirkov 1903: 145): »Речничкиот материјал да биде збир од сите македонски наречјащ.

Z ustanovitvijo Inštituta za makedonski jezik »Krste Misirkov« je delo na slovarju prevzel Inštitut. Obdelava se je začela v letu 1955. Gradivo za prvi zvezek je obdelano s strani tedanjih asistentov na Inštitutu za makedonski jezik:

- Todorja Dimitrovskega, ki je obdelal črke G, Đ, Z in DZ,

- Blagoja Korubina, ki je obdelal črke A, B, E, J, LJ, M in N,

- Trajka Stamatoskega, črke V, Ž in K, ter

- Borisa Markovega, ki je obdelal črki D in I.

V letu 1963 je bil velik potres v Skopju, ki je bil razlog za zamudno izdajo preostalih dveh zvezkov slovarja. Po potresu oz. po ustvarjanju normalnih pogojev za delo sta izšla drugi in tretji zvezek slovarja. Oba sta bila izdelana s strani tedanjih znanstvenih sodelavcev: 
- Todorja Dimitrovskega (črka P),

- Blagoja Korubina (črke O, T, KJ, U, Č, DŽ in Š) in

- Trajka Stamatoskega (črke R, S, F, H in C).

Črki O in P sta v drugem zvezku, medtem ko so vse ostale črke v tretjem zvez$\mathrm{ku}$. V tretjem zvezku so podana tudi zemljepisna imena in njihove izpeljanke (imena prebivalcev).

Posebej je treba poudariti prilogo Razlage (IX-X), ki je na začetku prvega zvezka slovarja, takoj za predgovorom, v kateri so razlage v sedmih točkah:

1. pisava (azbuka), ki vsebuje makedonsko pisavo in nekatere glasoslovne posebnosti: črki kj in gj nikoli ne stojita v začetku besede pred i-jem. Črka dz je zvočni par glasu c, v makedonščini ni besed, ki se začenjajo z nj;

2. naglas (') - naglas je označen tam, kjer gre za odstopanje od trizložnega naglaševanja;

3. samostalniki (m, f, n) - pri samostalnikih s premičnim samoglasnikom je podana končnica za množinsko obliko;

4. pridevniki (adj) - pri pridevnikih je podana oblika ženskega spola samo v primerih s premičnim samoglasnikom: верен -рна;

5. prislovi (adj);

6. glagoli - predstavljeni so z obliko za 3. osebo ednine v sedanjiku, ker makedonski jezik nima nedoločnika;

7. slogovne označbe - tukaj so podani kvalifikatorji: razg. - pogovorni jezik, dijal. - narečje, arh. - arhaična beseda in fraz. - frazeološki izraz.

Kakor vsi slovarji, tako tudi ta vsebuje seznam okrajšav, ki so v latinični pisavi. Primeri: adj - pridevnik, adv - prislov, inter - medmet, aor. - aorist, f - ženski spol, bot. - botanika, geogr. - zemljepis, istor. - zgodovina, mat. - matematika, med - medicina ipd.

Slovar makedonskega jezika s srbohrvaškimi prevodi po številu gesel sodi v srednje slovarje. V prvem zvezku je 29.359, v drugem 17.799 in v tretjem 17.364 gesel. Na koncu 3. zvezka je podana natančna številka: 64.522 besed.

\section{Slovar s stališča kodifikacije makedonskega jezika in njegova pomembnost}

Misirkova ideja in principi Komisije za pisavo in pravopis makedonskega jezika ter končna kodifikacija makedonskega jezika bi lahko ostali samo na papirju brez Slovarja makedonskega jezika s srbohrvaškimi prevodi. Pomembnost izida slovarja najdemo v naslednjih sklepih:

- če primerjamo Misirkove ideje in principe Komisije za pisavo in pravopis ter principe Koneskega, pridemo do zaključka, da obstaja skupna nit glede ideje o razvoju makedonskega knjižnega jezika. Slovar predstavlja uresničitev postavljenih principov; 
- makedonska pisava in pravopis makedonskega jezika sta doživela svojo aktualizacijo v praksi;

- z izidom vseh zvezkov slovarja se je zaokrožila kodifikacija makedonskega jezika;

- besedni zaklad slovarja je definiral osrednje govore makedonskega jezika kot jezikovno osnovo makedonskega knjižnega jezika. S tem je prišlo do potrditve skupnega principa o narečni osnovi makedonskega knjižnega jezika;

- z izdajo slovarja je prišlo do prvega popisa ogromnega števila makedonskih besed in svojevrstne stabilizacije makedonskega besedišča;

- slovar ima kot del procesa kodifikacije makedonskega knjižnega jezika normativno funkcijo;

- v slovarju najdemo veliko dialektnih besed, ki preko slovarja najdejo širšo uporabo v knjižnem jeziku;

- slovar vsebuje tujke in specialno terminologijo in s tem ponuja dobro osnovo za izdelavo prihodnjih slovarjev tujk in terminoloških slovarjev;

- s prilogo o zemljepisnih imenih in njihovih izpeljankah so se odprla nova področja $\mathrm{v}$ raziskavi makedonskega jezika in njegovega pravopisa ter besedotvorja;

- izid slovarja je zapolnil praznino v makedonskem jeziku oz. v makedonskem besedoslovju in slovaropisju;

- Slovar makedonskega knjižnega jezika s srbohrvaškimi prevodi ima dvojno vlogo. Prva vloga je leksikološke in leksikografske narave, medtem ko je druga medkulturne narave, ker je slovar pripadnikom ostalih južnoslovanskih narodov olajšal dostop do makedonskega jezika in makedonske književnosti;

- slovar je predstavljal stabilno osnovo za vse kasnejše slovarje makedonskega jezika Inštituta za makedonski jezik »Krste Misirkov«. Besedišče slovarja je v osnovi kasnejših slovarjev Inštituta za makedonski jezik »Krste Misirkov«:

- Obrnjeni slovar makedonskega jezika, v redakciji K. Koneskega in A. Džukeskega, ki je izšel 1967 (Обратен речник на македонскиот јазик, ред.: К. Конески и А. Џукески; составувач В. Миличиќ. Скопје 1967. 388 стр.),

- Pravopis makedonskega jezika s pravopisnim slovarjem, redakcijski odbor: B. Vidoeski, T. Dimitrovski, K. Koneski, K. Tošev, R. Ugrinova-Skalovska (Правопис на македонскиот литературен јазик со правописен речник, ред. одбор: Б. Видоески, Т. Димитровски, К. Конески, К. Тошев, Р. Угринова-Скаловска, Скопје 1970),

- Slovar makedonskega knjižnega jezika, zvezek I (A-Ž), gl. redaktor: K. Koneski, redakcija: S. Velkovska, K. Koneski, Ž. Cvetkovski, Inštitut za makedonski jezik »Krste Misirkov«, Skopje 2003 (skupina avtorjev) (Толковен речник на македонскиот јазик, том I (А-Ж), гл. редактор: К. Конески, ред.: С. Велковска, К. Конески, Ж. Цветковски, Институт за македонски јазик »Крсте Мисирков«, Скопје 2003 (група автори)), 
- Slovar makedonskega knjižnega jezika, zvezek II (Z-K), gl. redaktor: K. Koneski, redakcija: S. Velkovska, K. Koneski, Ž. Cvetkovski, Inštitut za makedonski jezik »Krste Misirkov«, Skopje 2005 (skupina avtorjev) (Толковен речник на македонскиот јазик, том II (3-K) гл. редактор: К. Конески, ред.: С. Велковска, К. Конески, Ж. Цветковски, Институт за македонски јазик »Крсте Мисирков«, Скопје 2005 (група автори)),

- Slovar makedonskega jezika, avtor Zoze Murgovski, 2005, Filološki fakultet Blaže Koneski (Речник на македонскиот јазик, автор Зозе Мурговски, 2005, Филолошки факултет Блаже Конески),

- Slovar makedonskega knjižnega jezika, zvezek III (L-O), gl. redaktor: K. Koneski, redakcija: S. Velkovska, K. Koneski, Ž. Cvetkovski, Inštitut za makedonski jezik »Krste Misirkov«, Skopje 2006 (skupina avtorjev) (Толковен речник на македонскиот јазик, том III (Л-О), гл. редактор: К. Конески, ред.: С. Велковска, К. Конески, Ж. Цветковски, Институт за македонски јазик »Крсте Мисирков«, Скопје 2006 (група автори)),

- Slovar makedonskega knjižnega jezika, zvezek IV (P), gl. redaktor: K. Koneski, redakcija: S. Velkovska, K. Koneski, Ž. Cvetkovski, Inštitut za makedonski jezik »Krste Misirkov«, Skopje 2008 (skupina avtorjev) (Толковен речник на македонскиот јазик, том IV (П), гл. редактор: К. Конески, ред.: С. Велковска, К. Конески, Ж. Цветковски, Институт за македонски јазик »Крсте Мисирков«, Скопје 2008 (група автори)),

- Slovar makedonskega knjižnega jezika, zvezek V (R-S), gl. redaktor: K. Koneski, redakcija: S. Velkovska, K. Koneski, Ž. Cvetkovski, Inštitut za makedonski jezik »Krste Misirkov«, Skopje 2011 (skupina avtorjev) (Толковен речник на македонскиот јазик, том IV (P-C), гл. редактор: К. Конески, ред.: С. Велковска, К. Конески, Ж. Цветковски, Институт за македонски јазик »Крсте Мисирков«, Скопје 2011 (група автори)),

- Slovar makedonskega knjižnega jezika, zvezek VI (T-Š), gl. redaktor: K. Koneski, redakcija: S. Velkovska, K. Koneski, Ž. Cvetkovski, Inštitut za makedonski jezik »Krste Misirkov«, Skopje 2014 (skupina avtorjev) (Толковен речник на македонскиот јазик, том VI (T-Ш), гл. редактор: К. Конески, ред.: С. Велковска, К. Конески, Ж. Цветковски, Институт за македонски јазик »Крсте Мисирков«, Скопје 2014 (група автори)).

Potrditev naših ugotovitev v zvezi s pomembnostjo slovarja najdemo pri Blažetu Koneskem (1981b: 189):

Може слободно да кажеме, од денешна перспектива, дека појавата на Речникот значеше многу повеќе во психолошка смисла, бидејќи придонесе за зацврстување на самото чувство на стабилноста на младиот литературен јазик. Се внесуваше ред и прегледност во една област што немаше дотогаш сосем јасни оцрти, и од самото тоа произлегуваше релаксација во културно-активната средина. Меѓутоа, и повеќе од тоа, изборот направен во Речникот, со сета толеранција, но и со примена на стилистичка оцена на вклучените единици, го посочуваше доволно јасно лексичкото јадро на литературниот јазик. 
V predgovoru slovarja (1994: VIII) je podana razlaga, ki podpira našo ugotovitev o pomembnosti slovarja za makedonsko slovaropisje:

Работата над првиот македонски речник, сврзана со ред тешкотии како и секоја почетна работа, претставуваше и една школа во која се стекна опит што корисно ќe послужи во натамошната разработка на македонската лексикографија.

Slovar je vplival na razvoj tedanjega mladega makedonskega knjižnega jezika, okrepil njegovo narečno osnovo in samostojnost ter odprl pot za nadaljnje raziskave na področju makedonskega besedoslovja in slovaropisja. Za pravopisom in slovnico makedonskega jezika je Slovar makedonskega jezika s srbohrvaškimi prevodi najbolj bistvena izdaja, ki je makedonskemu jeziku omogočila samostojnost in neodvisnost v slavistiki in širše.

\section{VIRI IN LITERATURA}

Istorija na makedonskiot narod I, 1969. Skopje: NIP Nova Makedonija.

Istorija na makedonskiot narod II, 1969. Skopje: NIP Nova Makedonija.

Istorija na makedonskiot narod III, 1969. Skopje: NIP Nova Makedonija.

Blaže KONESKI, 1981a: Gramatika na makedonskiot literaturen jazik. Skopje: Kultura, Makedonska kniga, Misla, Naša Kniga.

- -, 1981b: Za makedonskiot literaturen jazik. Skopje: Kultura, Makedonska kniga, Misla, Naša Kniga.

- -, 1996: Istorija ma makedonskiot jazik. Skopje: Detska radost.

Krste PETKOV MISIRKOV, 1903: Za makedonckite raboti. Sofija: Pečatnica na Liberalnii klub.

Rečnik na makedonskiot jazik so srpskohrvatski tolkuvanja I (3. izdaja), 1994. Skopje: Detska radost.

Rečnik na makedonskiot jazik so srpskohrvatski tolkuvanja II (3. izdaja), 1994. Skopje: Detska radost.

Rečnik na makedonskiot jazik so srpskohrvatski tolkuvanja III (3. izdaja), 1994. Skopje: Detska radost.

THE FIRST MACEDONIAN LANGUAGE DICTIONARY FROM THE STANDPOINT OF THE CODIFICATION OF THE MACEDONIAN LANGUAGE

The publication of the first Macedonian language dictionary finished the process of codification of the Macedonian language. This dictionary has played a significant role in the actualization of the main principles of the codification of Macedonian language: the 
actualization of the Macedonian alphabet and the stabilization of Macedonian vocabulary. At the same time it has influenced the development of Macedonian lexicography. After Macedonian orthography and grammar, the Macedonian language dictionary with Serbo-Croatian translations is the most crucial issue that has given the Macedonian language autonomy and independence in Slavic studies and beyond. 